\title{
Modifikasi Senjata Anggar Untuk Meningkatkan Kekuatan Otot Lengan Pada Atlet Anggar Pemula
}

\section{Modification of Fencing Weapons to Increase Strength Arm Muscles in Beginner Fencing Athletes}

\author{
Atri Widowati ${ }^{1}$, Grafitte Decheline ${ }^{2}$ \\ 1,2 Jurusan Pendidikan Olahraga dan Kepelatihan, Fakultas Keguruan dan IImu Pendidikan, \\ Universitas Jambi, Indonesia \\ email: atri.widowati@unja.ac.id11 ,grafiti@unja.ac.id²
}

doi: https://doi.org/10.20884/1.paju.2020.2.1.3331

\begin{abstract}
Abstrak
Olahraga Anggar merupakan salah satu olahraga yang sedang dikembangkan di Jambi, terkhusus di Universitas Jambi. Karena merupakan olahraga yang baru mulai dikembangkan di Jambi, maka banyak kendala yang dihadapi oleh pelatih, atlet dan pengurus Anggar di Universitas Jambi (UKM). Salah satu kendala yang sangat besar adalah ketersediaan senjata untuk atlet. Dikarenakan hal tersebut, maka peneliti ingin memodifikasi senjata yang dapat digunakan oleh atlet dengan menyesuaikan dengan kebutuhan atlet di Universitas Jambi. Tujuan dari penelitian ini adalah untuk memodifikasi senjata anggar yang dapat digunakan atlet sekaligus melatih kekuatan otot lengan atlet. Penelitian ini menggunakan penelitian Research and Development (RnD) dimana tahapan yang digunakan adalah menggunakan ADDIE yaitu kegiatan meliputi Analisys, Design, Development, Implementation and Evaluating. Tahapan penelitian ini akan melibatkan 10 orang atlet Anggar di Universitas Jambi, 3 orang expert, baik dari pelatih, dan official pengurus Anggar di Provinsi Jambi. Berdasarkan penelitian yang telah dilakukan, mulai dari tahapan desain alat hingga pengumpulan google form efektivitas senjata yang dimodifikasi $70 \%$ efektif untuk meningkatkan kekuatan otot lengan pada atlet Anggar di Universitas Jambi.
\end{abstract}

Kata Kunci : Angar, Kekuatan Otot, Senjata, Modifikasi

\begin{abstract}
Fencing is a sport that is being developed in Jambi, especially at Jambi University. Because it is a sport that is just starting to be developed in Jambi, there are many obstacles faced by coaches, athletes and fencing administrators at Jambi University (UKM). One of the biggest obstacles is the availability of weapons for athletes. Due to this, the researchers wanted to modify the weapons that can be used by athletes to suit the needs of athletes at Jambi University. The purpose of this study was to modify the fencing weapon that athletes can use as well as to train the athlete's arm muscle strength. This study uses Research and Development (RnD) research where the stages used are using ADDIE, namely activities include Analysis, Design, Development,
\end{abstract}

Alamat Koresponden : Jurusan Pendidikan Olahraga dan Kepelatihan, Fakultas Keguruan dan Ilmu Pendidikan, Universitas Jambi

Email : grafiti@unja.ac.id

\section{(c) (i)}

Jurnal Physical Activity Journal (PAJU) This work is licensed under a Creative Commons Attribution 4.0 International License. 
Implementation and Evaluating. This research stage will involve 10 fencing athletes at Jambi University, 3 experts, both from coaches, and the official board of fencing in Jambi Province. Based on the research, starting from the stage of tool design to collecting google form the effectiveness of modified weapons is $70 \%$ effective for increasing arm muscle strength in fencing athletes at Jambi University.

Keywords : Fencing, Muscle Strength, Weapons, Modify

\section{PENDAHULUAN}

Anggar merupakan salah satu cabang olahraga yang dipertandingkan di Olimpiade sejak tahun 1896. Olahraga ini merupakan salah satu olahraga beladiri. Namun olahraga Anggar menggunakan senjata sebagai sarana pertahanan diri (Decheline \& Rasyono, 2019). Olahraga anggar sebenarnya sudah dikenal sangat lama oleh para bangsawan kerajaan. Anggar merupakan salah satu olahraga yang digunakan sebagai penanda kekuasaan oleh bangswan kerjaan terdahulu di belahan Bagian Eropa. Para bangsawan menggunakan anggar sebagai pertarungan untuk membuktikan kekuatan mereka terhadap orang lain atau bangsa lain.

Anggar diikutsertakan dalam PON pertama kali pada tahun 1948 di Solo, Jawa Tengah sebagai olahraga eksibisi (Kurniawan, 2010b). Setelah itu, Anggar menjadi olahraga wajib yang diikutsertakan di PON. Anggar dipopulerkan pertama kali pada anggota-anggota TNI AL sebagai olahraga wajib. Indonesia memilik Sekolah Olahraga Militer di Bandung untuk 3 jenis senjata, foil, epee dan sabre yang masa pendidikannya adalah selama 3 tahun. Sedangkan di Magelang, para anggota militer juga memiliki Sekolah Olahraga Militer dengan fokus senjata Sabre dan pendidikan selama 1 tahun.(Kurniawan, 2010b)

Di Jambi sendiri, anggar serentak di bentuk pada tahun 1981 di seluruh Indonesia termasuk di Jambi. Menjadi populer di kala itu hingga tahun 1990-an. Namun semakin tahun prestasi di Jambi semakin menurun dikarenakan banyak sponsor yang mundur, selain itu regenerasi atlet dan pembinaan yang kurang juga mengakibatkan Anggar Jambi semakin sepi peminat dan atlet.

Berkembangnya permainan anggar di Indonesia membawa dampak yang baik pula bagi Anggar Jambi. Pelan-pelan Anggar Jambi bangkit untuk membuktikan eksistensinya. Semakin banyak atlet yang mengikuti Anggar, seperti halnya di Universitas Jambi. UKM Anggar di UNJA dibentuk untuk memfasilitasi peminat olahraga pedang ini. 
Atri Widowati, Grafitte Decheline | Modifikasi Senjata Anggar Untuk Meningkatkan Kekuatan Otot Lengan Pada Atlet Anggar Pemula

Berbagai aspek yang dapat mempengaruhi performa dan peningkatan keterampilan dari seorang atlet anggar. Aspek kekuatan, kelincahan, endurance, power baik lengan dan tungkai, koordinasi, keseimbangan, reaksi, kecepatan, ketepatan dan kelentukan harus dimiliki oleh seorang atlet anggar. Kekuatan digunakan untuk mengukur seberapa kemampuan yang dapat dihasilkan untuk dapat mengendalikan senjata (Chan, 2012). Power otot lengan juga sangat diperlukan karena pada olahraga ini untuk mendapatkan poin ataupun menang, atlet harus bisa melakukan touche' kepada lawan. Touche' dilakukan bukan menggunakan tubuh secara langsung, namun menggunakan senjata (weapon) sebagai media. Senjata pada anggar terbagi menjadi 3 klasifikasi, yaitu foil, epee, dan sabre (Widowati \& Decheline, 2018). Ketiganya memiliki berat yang berbeda, sesuai dengan sasaran dan kalsifikasi dari senjata tersebut.

Berat yang berbeda pada senjata yang digunakan, juga membutuhkan effort yang berbeda pada setiap atlet. Senjata epee merupakan senjata dengan berat yang paling besar, yaitu sebesar 750-770 gram, sedangkan untuk senjata sabre dan foil memiliki berat 500 gram (wikipedia, 2020). Peraturan permainan di Anggar, atlet bermain selama 3 menit dalam 3 babak, dengan jeda antar babak 1 menit. Atau jika perolehan poin lebih dahulu dicapai sebanyak 15 poin. Sehingga seorang atlet sangat membutuhkan power otot lengan untuk dapat menahan senjata selama 3 menit tanpa lengah agar tidak terkena touche' dari lawan.

Olahraga Anggar merupakan salah satu olahraga "mahal", hal ini dikarenakan equipment atau peralatan yang dibutuhkan oleh satu orang atlet tidak murah. Senjata saja berkisar antara 1 juta hingga 5 juta. Kebutuhan lainnya yang wajib dipenuhi seperti baju dengan standar 350 Newton, Masker yang juga harus sesuai standar $350 \mathrm{~N}$, sarung tangan khusus anggar, body wire, mask wire, hingga kaos kaki yang harus menutupi seluruh tulang kering. Jika seorang atlet pemula harus memenuhi seluruh kebutuhan yang diperlukan, maka bisa dipastikan Anggar akan sepi peminat. Harga "mahal" yang ditawarkan belum tentu akan sebanding dengan prestasi yang dicapai. Namun jika seorang atlet ingin berlatih tanpa memiliki peralatan yang dibutuhkan tersebut, maka bisa dimungkinkan atlet tidak dapat berprestasi dengan baik. Perlu beberapa tahapan dan waktu untuk dapat melengkapi kebutuhan tersebut, seperti senjata, baju, masker, sarung tangan,sepatu, wire, rolling, recording hingga ke piste (Pertiwi, 2012). Namun hal-hal 
tersebut harus sedikit demi sedikit dipenuhi guna kelancaran latihan untuk pembinaan atlet berprestasi.

Hal tersebutlah yang memberikan ide kepada peneliti untuk membantu atlet Anggar memenuhi kebutuhan untuk latihan mereka. Peneliti ingin memodifikasi senjata Anggar untuk keperluan latihan sehari-hari. Karena jika menggunakan senjata asli langsung, selain karena harganya yang mahal, untuk pemula yang baru berlatih Anggar, senjata yang biasa digunakan dalam pertandingan rawan untuk patah. Untuk dapat membantu atlet dalam berlatih anggar sehari-hari, peneliti ingin memberikan kemudahan dengan memodifikasi senjata. Senjata yang dimodifikasi juga akan diberikan beban, tujuan beban yang diberikan pada senjata yang dimodifikasi adalah untuk sekaligus melatih kekuatan otot lengan atlet anggar pemula di Universitas Jambi.

Untuk mengatasi permasalahan tersebut maka, perlu dilakukan penelitian mengenai modifikasi senjata anggar untuk meningkatkan kekuatan otot lengan pada atlet anggar pemula di UKM Anggar Universitas Jambi. Tujuan penelitian ini yaitu untuk membangkat senjata anggar modifikasi yang dapat digunakan untuk meningkatkan kekuatan otot lengan.

\section{METODE}

Penelitian ini merupakan penelitian yang akan langsung diterapkan kepada atlet. Jumlah keseluruhan atlet yang menjadi subjek penelitian berjumlah 10 orang. Menggunakan ketetapan, bahwa yang dapat mengikuti penelitian ini adalah atlet yang baru saja bergabung di dalam klub Anggar di Universitas Jambi. Atlet yang sudah lama menjadi atlet Anggar di Universitas Jambi, akan menjadi kelompok kontrol untuk mengetahui apakah ada peningkatan pada atlet pemula menggunakan senjata yang dimodifikasi atau tidak.

Model yang digunakan dalam pengembangan ini adalah model ADDIE. (Junaedi, 2016) Model ADDIE ini adalah singkatan untuk lima tahap proses pengembangan, yaitu Analysis (Analisis), Design (Desain), Development (Pengembangan), Implement (Implementasi), dan Evaluation (Evaluasi). Model ADDIE bergantung pada setiap tahap yang dilakukan dalam urutan yang diberikan, namun dengan fokus pada refleksi dan 
Atri Widowati, Grafitte Decheline | Modifikasi Senjata Anggar Untuk Meningkatkan Kekuatan Otot Lengan Pada Atlet Anggar Pemula

iterasi. Model ini memberi pendekatan yang terfokus pada pemberian umpan balik untuk perbaikan terus-menerus. (Tegeh \& Kirna, 2013)

\section{ADDIE Instructional Design Model}

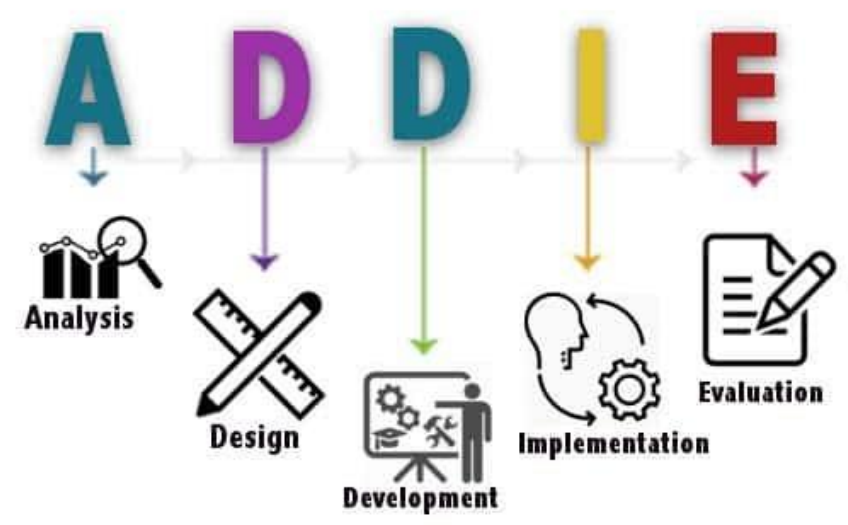

Gambar 1. Model Pengembangan ADDIE

Model ADDIE berdasarkan Cahyadi (2019), terdiri dari lima fase atau tahapan utama, yaitu:

\section{Analysis}

Analisis merupakan langkah pertama dari model design sistem pemeblajaran ADDIE. Analisis ini betujuan untuk mengetahui dan mengklarifikasi apakah masalah kinerja yang dihadapi memerlukan solusi berupa modifikasi senjata anggar untuk latihan. Selain itu berdasarkan dengan Analisa kebutuhan, apakah langkah yang diperlukan untuk menentukan kemampuan-kemampuan atau hal-hal yang perlu dipelajari oleh atlet. Apakah alat yang akan dikembangkan memang dibutuhkan oleh atlet dalam proses latihan.

\section{Design}

Design merupakan langkah kedua dari model ADDIE. Langkah ini merupakan:

a. Inti dari langkah analisa karena mempelajari masalah kemudian menemukan alternatif solusinya yang berhasil diidentifikasi melalui langkah analisis kebutuhan.

b. Langkah penting yang perlu dilakukan untuk menentukan prosedur dan sarana prasarana yang dibutuhkan saat latihan. 
c. Langkah yang harus mampu menjawab apakah modifikasi yang dilakukan dapat mengatasi atau mampu membantu meningkatkan masalah kekuatan lengan atlet anggar.

\section{Development}

Pengembangan adalah langkah model ADDIE yang ketiga. Langkah pengembangan meliputi kegiatan membuat, membeli, dan memodifikasi senjata anggar. Dengan kata lain mencakup kegiatan memilih, menentukan metode, media yang sesuai untuk digunakan dalam latihan Anggar. Dalam melakukan langkah pengembangan, ada dua tujuan penting yang perlu dicapai, antara lain:

a. Produksi, pembelian atau revisi produk senjata anggar yang dimodifikasi telah ditetapkan sebelumnya

b. Memilih media atau kombinasi perlengkapan yang terbaik, efektif, efisien dan aman untuk digunakan atlet

\section{Implementation}

Implementasi atau penyapaian materi pembelajaran merupakan langkah keempat dari model ADDIE. Tujuan utama dari langkah ini adalah:

a. Membimbing atlet untuk mencapai kompetensi latihan yang tepat

b. Menjamin terjadinya pemecahan solusi yang terbaik untuk mengatasi permasalahan yang mencuat.

c. Memastikan bahwa modifikasi senjata anggar dapat digunakan oleh atlet dengan baik

\section{Evaluation}

Evaluasi merupakan langkah akhir dari model desain ADDIE. Evaluasi adalah proses yang dilakukan untuk memberikan nilai terhadap pengembangan yang dilakukan. Tujuan adanya evaluasi adalah untuk:

a. Mengetahui bagaimana dampak modifikasi alat terhadap atlet

b. Mengetahui peningkatan kompetensi kekuatan lengan dengan adanya alat tersebut

c. Keuntungan apa yang dirasakan oleh atlet dengan adanya modifikasi alat tersebut.

Dalam penelitian ini akan digunakan teknik ADDIE untuk memodifikasi alat yang akan digunakan untuk meningkatkan kekuatan otot lengan atlet. 
Atri Widowati, Grafitte Decheline | Modifikasi Senjata Anggar Untuk Meningkatkan Kekuatan Otot Lengan Pada Atlet Anggar Pemula

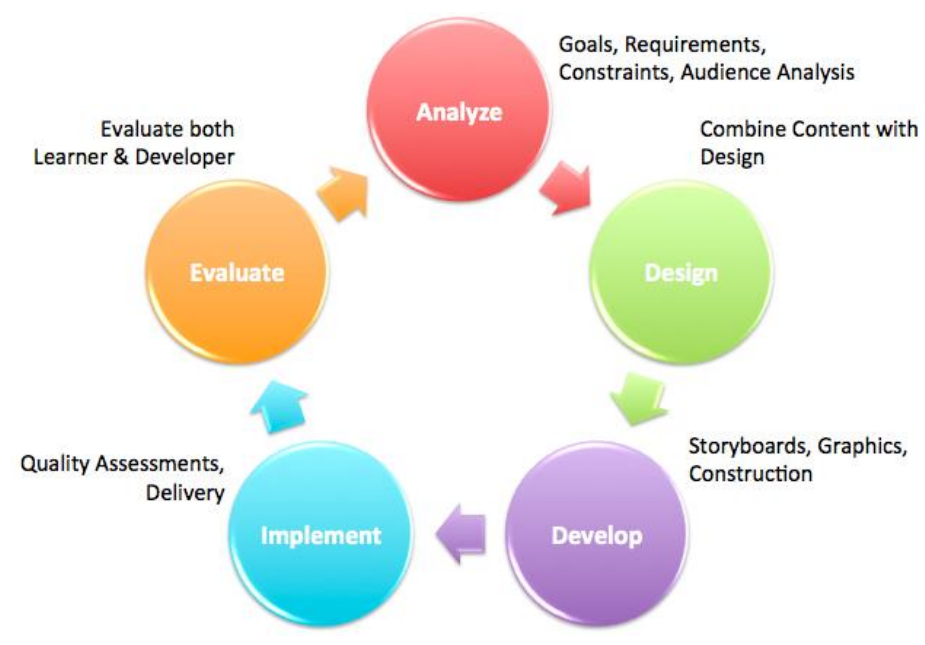

Gambar 2. Langkah Penelitian (Keung, 2017)

\section{1) Pengumpulan Data}

Pengumpulan data dilakukan dari lapangan dan studi literatur yang dapat digunakan sebagai bahan untuk perencanaan produk tertentu yang diharapkan mengatasi masalah. Pada tahap pengumpulan data ini peneliti melakukan wawancara dan melakukan observasi dilapangan FIK Universitas Jambi untuk mengetahui permasalahan yang dihadapi khususnya di modifikasi senjata anggar untuk meningkatkan kekuatan otot lengan atlet.

\section{2) Desain Produk}

Berdasarkan identifikasi masalah tersebut, maka langkah selanjutnya adalah pembuatan produk modifikasi senjata anggar. Dalam pembuatan produk yang dikembangkan, peneliti membuat produk berdasarkan kajian teori yang kemudian dievaluasi oleh satu dosen ahli media dan satu pelatih anggar sebagai ahli materi, serta uji coba kelompok kecil. Modifikasi senjata anggar yang akan dikembangkan ini berfungsi untuk media untuk meningkatkan kekuatan otot lengan atlet anggar, maka dari itu pemberat di buat untuk membiasakan tangan menjadi lebih kuat. Media dari modifikasi senjata anggar ini dibuat menggunakan alat dan bahan yang dapat dengan mudah ditemukan. Bahan pembuatan media :
a. Potongan Pipa
d. Semen
b. Fiber
e. Pasir
c. Batok Kelapa 
Kegunaan dari modifikasi senjata anggar yang peneliti buat adalah sebagai alternatif media senjata yang jika beli senjata anggar membutuhkan dana yang tidak sedikit. Selain itu, senjata yang dimodifikasi juga diberikan pemberat di bagian pegangannya, hal ini bertujuan untuk membantu atlet agar dapat melatih kekuatan otot lengan dari atlet tersebut.

\section{3) Validasi Produk}

Validasi produk merupakan proses kegiatan untuk menilai rancangan produk. Validasi masih bersifat penilainan bedasarkan rasional dari para ahli dan praktisi, dan belum pengujian yang bersifat pengujian fakta lapangan. Validasi dapat dilakukan dengan cara menghadirkan beberapa pakar atau tenaga ahli dan praktisi yang sudah berpengalaman unutuk menilai produk baru yang dirancang. Dalam penelitian ini, validator adalah pelatih utama Anggar di Provinsi Jambi, dan Asisten pelatih fisik di Provinsi Jambi serta asisten pelatih teknik di Kota Jambi. Total validator adalah 3 orang sesuai dengan keahlian baik di bidang teknik maupun fisik.

\section{4) Revisi Produk}

Setelah desain produk divalidasi melalui diskusi dengan pakar dan ahli lainya, maka akan dapat diketahui kelemahanya. Kelemahan tersebut selanjutnya dicoba untuk dikurangi dengan cara memperbaiki desain. Yang bertugas memperbaiki desain adalah peneliti.

\section{5) Uji Coba Produk}

Setelah desain produk direvisi, kemudian peneliti membuat produk sesuai dengan desain yang di revisi. Setelah itu, dilakukan penggunaan pada skala kecil dengan menggunakan subyek uji coba 5 atlet Anggar Universitas Jambi untuk mengetahui tanggapan atlet mengenai modifikasi senjata anggar ini.

\section{6) Revisi Produk}

Dalam uji coba skala kecil, tentunya terdapat kekurangan dalam produk, kemudian kekurangan ini direvisi untuk memperkecil kemungkinan adanya kelemahan dalam produk.

\section{7) Uji Coba Pemakaian}

Setelah produk direvisi dan dinyatakan layak untuk digunakan maka, produk yang dikembangkan di uji coba dengan skala besar dengan menggunakan subyek uji coba 10 atlet Anggar Universitas Jambi. 
Atri Widowati, Grafitte Decheline | Modifikasi Senjata Anggar Untuk Meningkatkan Kekuatan Otot Lengan Pada Atlet Anggar Pemula

\section{8) Revisi Produk Akhir}

Revisi dilakukan, jika terdapat kelemahan dan kekurangan dalam uji coba di tim Anggar Universitas Jambi. Kemudian kelemahan dan kekurangan itu disempurnakan.

\section{9) Implementasi Model}

Desiminasi dan implementasi, yaitu menyampaikan hasil pengembangan (proses prosedur atau produk) kepada para pengguna dan profesional dalam bentuk jurnal, atau dalam bentuk buku.

Instrumen adalah suatu alat yang karena memenuhi persyaratan akademis maka dapat dipergunakan sebagai alat untuk mengukur suatu obyek ukur atau mengumpulkan data mengenai suatu variabel (Sugiyono, 2014). Teknik pengambilan sampel pada umumnya dilakukan secara random, pengumpulan data menggunakan instrumen penelitian, analisis data bersifat kuantitatif/statistik dengan tujuan untuk menguji hipotesis yang telah ditetapkan (Sugiyono, 2016). Instrumen yang digunakan untuk mengumpulkan data adalah lembar kuesioner. Lembar kuesioner digunakan untuk menghimpun data dari para ahli terkait dengan model yang dikembangkan dan menilai apakah modifikasi senjata anggar efektif dan efisien untuk menjadi alat latihan pengganti dalam olahraga Anggar bagi atlet pemula Anggar Universitas Jambi. Kuesioner untuk ahli dan untuk atlet digunakan untuk mengumpulkan data dari evaluasi ahli dan dalam uji coba.

\section{HASIL}

Data dalam penelitian ini diperoleh dengan melaksanakan pembuatan model senjata yang akan dimodifikasi. menggunakan konsep ADDIE, yaitu Analysis, Development, Design, Implementation, dan Evaluating. Berdasarkan dengan hasil penelitian, modifikasi senjata anggar yang telah dibuat kemudian diberikan kepada atlet pemula. Sebagai perbandingan adalah atlet Senior yang tidak menggunakan modifikasi senjata sebagai bantuan dalam meningkatkan kekuatan lengan mereka (Kurniawan, 2010a). Hasil penelitian diperoleh dari Google Form yang diberikan kepada atlet. Hasil modifikasi alat yang telah di design sebelumnya adalah seperti Gambar 3. dibawah ini. 


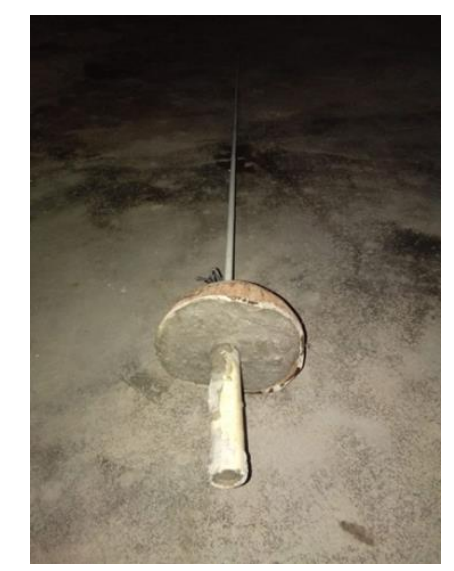

Gambar 3. Modifikasi Senjata

Sedangkan untuk senjata yang tidak dimodifikasi terlihat seperti Gambar 4.dibawah ini.

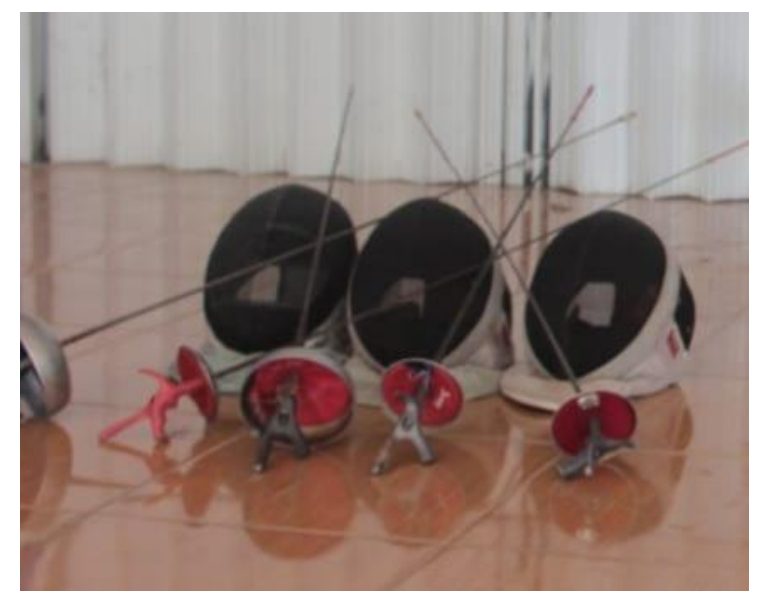

Gambar 4. Senjata Foil dan epee dalam Anggar

Dari kedua gambar di atas, dapat terlihat perbedaan di bagian grip atau pegangan senjata. Pada senjata yang sebenarnya hanya terdapat grip berbentu pistol yang memudahkan atlet untung memegang tanpa resiko cedera, namun berat beban senajta terletak pada kom dan kling (bilah senjata). Sedangkan pada senjata yang dimodifikasi, kom dan grip sedikit dirubah. Kom dimodifikasi menjadi lebih berat dalam hal beban dibanding dengan senjata sebenarnya. Dan untuk kom yang digunakan dalam senjata modifikasi berbentuk lurus adalah untuk melatih sedikit demi sedikit kemampuan dari atlet pemula. Sedangkan untuk bilah senjata, pada senjata foil, epee maupun sabre yang sesungguhnya digunakan dari material besi lentur dengan tingkat kelenturan yang berbeda-beda tergantung pada jenis dan spesifikasi senjata tersebut. Sedangkan untuk senjata yang dimodifikasi, digunakan fiber pancing. Penggunaan fiber pancing bertujuan 
Atri Widowati, Grafitte Decheline | Modifikasi Senjata Anggar Untuk Meningkatkan Kekuatan Otot Lengan Pada Atlet Anggar Pemula

untuk menghemat pengeluaran (budget) artinya para atlet dapat membuat sendiri di rumah perihal alat ini.

Berdasarkan hal tersebutlah, maka atlet diminta untuk membuat sendiri senjata yang dimodifikasi. Namun peneliti telah lebih dahulu membuat, sehingga dapat dicontoh oleh para atlet. Berat pada kom dapat disesuaikan dengan kemampuan atlet. Namun tidak boleh terlalu ringan dan tidak boleh pula terlalu sedang. Maksimal beban yang dikehendaki adalah $1.5 \mathrm{~kg}$. atlet diminta untuk mengirimkan foto yang menunjukkan bahwa mereka menggunakan senjata modifikasi tersebut untuk berlatih.

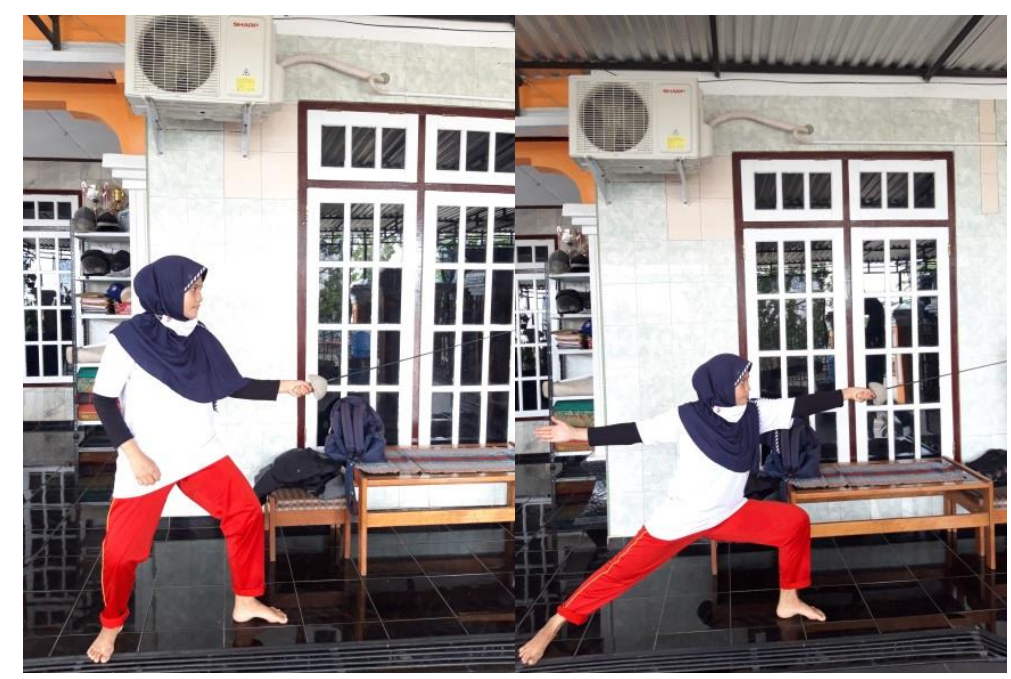

Gambar 5. Atlet berlatih dengan senjata modifikasi

Pemberian google form bertujuan sebagai pengganti kuesioner kepada atlet. Dikarenakan pandemi Covid-19 yang melanda Indonesia dimulai bulan Maret 2020, sehingga peneliti tidak dapat memberikan dan bertatap muka secara langsung kepada atlet.

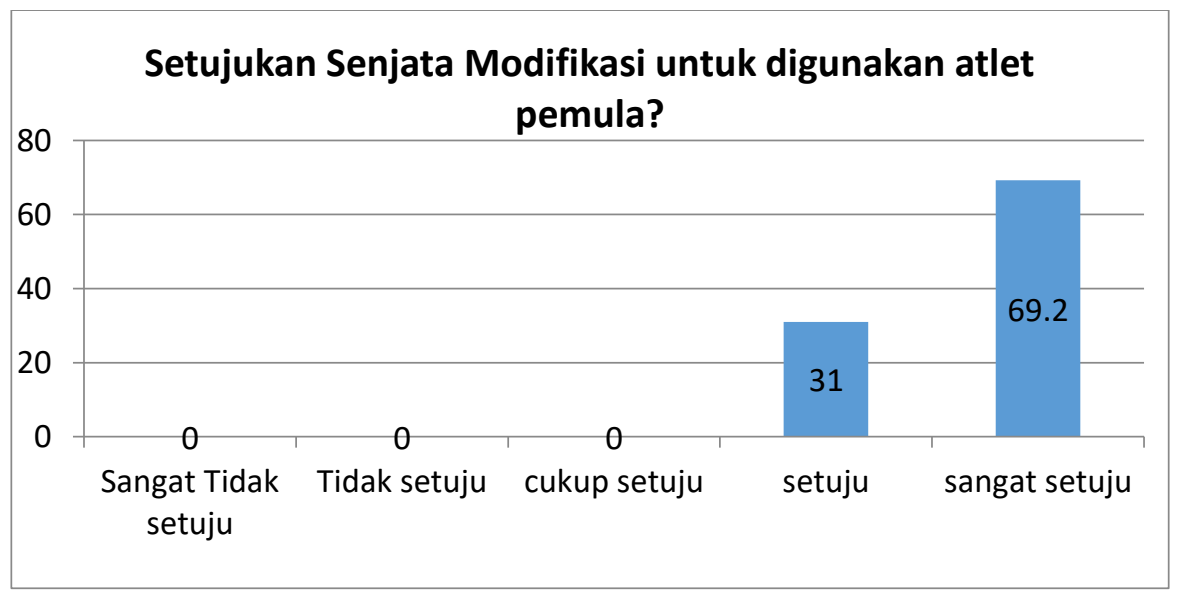

Gambar 6. Kuesioner 1 
Berdasarkan dengan Kuesioner yang diberikan kepada atlet pemula, diketahui bahwa 9 orang atlet dari 13 orang atlet yang memberikan respon mengatakan bahwa media yang dimodifikasi sudah sangat sesuai dengan karakteristik atlet. Sasaran atlet yang menggunakan modifikasi senjata ini adalah atlet pemula yang memang kegunaan dari senjata modifikasi tersebut adalah untuk meningkatkan kekuatan otot lengan pada atlet.

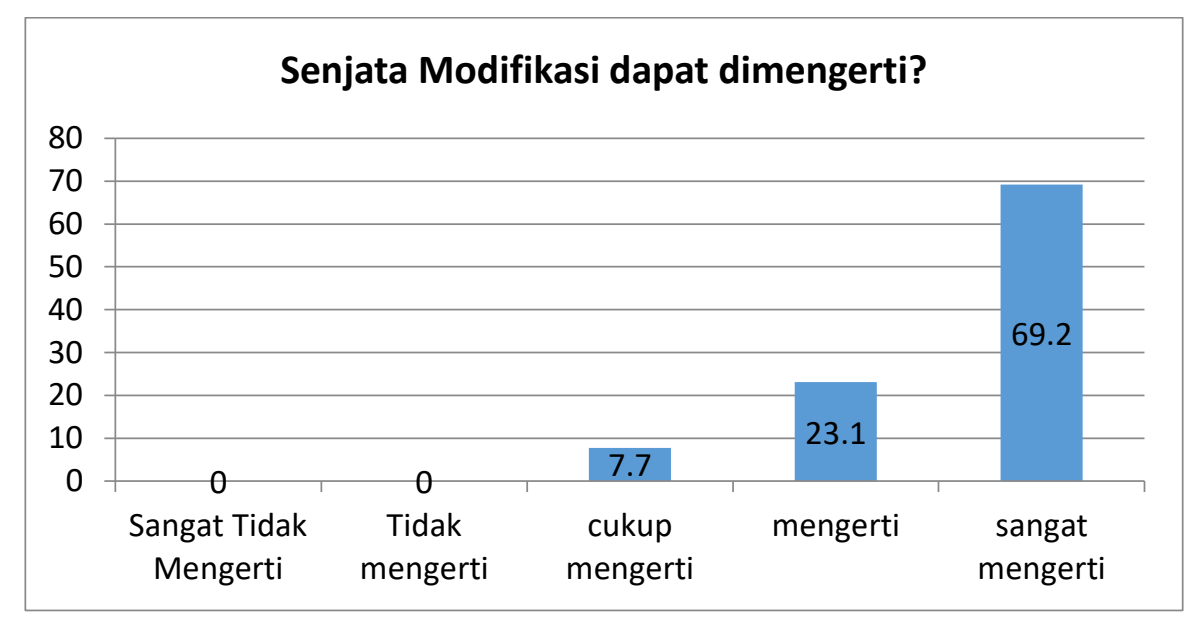

Gambar 7. Kuesioner 2

Selain dari kesesuaian media latihan yang dimodifikasi sesuai dengan karakteristik atlet yang menjadi sasaran, modifikasi senjata anggar pun juga sangat mudah dimengerti, baik dari segi kegunaan dan manfaat dari senjata modifikasi tersebut. Sebanyak $69.2 \%$ atlet menyatakan bahwa sangat setuju bahwa senjata modifikasi sangat mudan dimengerti.

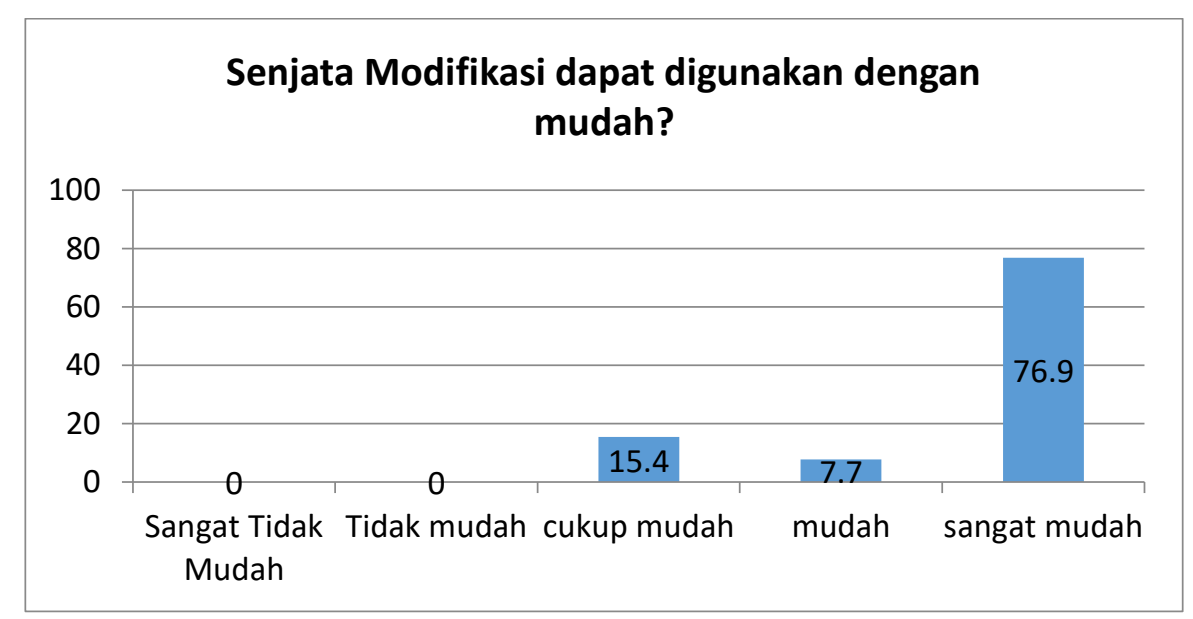

Gambar 8. Kuesioner 3 
Atri Widowati, Grafitte Decheline | Modifikasi Senjata Anggar Untuk Meningkatkan Kekuatan Otot Lengan Pada Atlet Anggar Pemula

Berdasarkan hasil penelitian dari pertanyaan yang diajukan kepada atlet Anggar pemula di UKM Universitas Jambi, sebnyak $76.9 \%$ dari atlet mengatakan bahwa media latihan atau senjata yang dimodifikasi sangat mudah dalam penggunaannya. Lebih memudahkan bagi pemula karena bentuk modifikasinya sederhana namun memiliki manfaat yang besar untuk membentuk kekuatan otot lengan serta power otot lengan dari atlet.

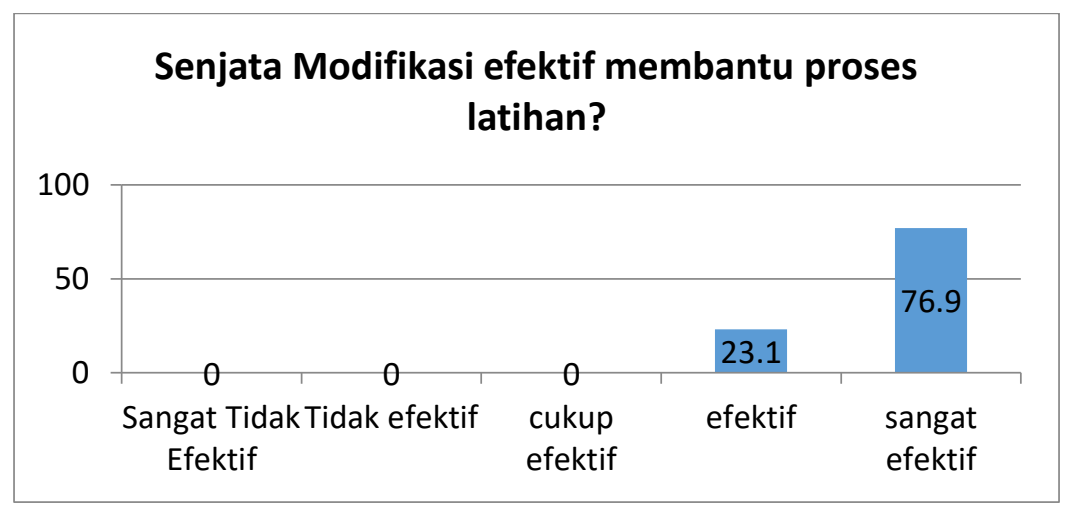

Gambar 9. Kuesioner 4

Media latihan yang dikembangkan dengan memodifikasi senjata juga sangat efektif membantu dalam proses latihan Anggar. 10 dari 13 orang atlet yang diberikan pertanyaan menyatakan bahwa modifikasi senjata anggar sangat efektif membantu atlet dalam latihan, khususnya untuk membentuk otot dan kekuatan lengan.

\section{PEMBAHASAN}

Modifikasi senjata dalam penelitian bertujuan untuk memfasilitasi atlet yang ada di Universitas Jambi untuk dapat tetap berlatih dengan baik. Dikarenakan keterbatasan dana untuk memiliki senjata tersebut bagi kebanyakan mahasiswa, maka dibuat versi senjata yang lebih ekonomis namun bernilai tinggi. Artinya, senjata yang telah dimodifikasi memiliki fungsi yang hampir sama namun lebih menitikberatkan pada pembentukan otot lengan atlet. Jika senjata pada umumnya digunakan untuk menusuk, memiliki berat $500-1100 \mathrm{gr}$, maka senjata yang dimodifikasi memiliki berat $\pm 1500 \mathrm{gr}$ dan tidak dapat digunakan untuk menusuk. Menggunakan semen pada pegangan (grip) diharapkan dapat memberikan beban yang berlebih pada bagian tangan hingga lengan. 
Olahraga Anggar, merupakan salah satu olahraga yang tidak murah. Dengan kebutuhan perlengkapan yang harus dimiliki oleh seorang atlet. Maka untuk awal perkenalan untuk dapat semakin mengembangkan cabang olahraga ini, pelatih dan pengurus Anggar harus memiliki ide-ide kreatif untuk menarik minat dan ketertarikan masyarakat atau siswa-siswa di sekolah. Modifikasi senjata anggar mendapat respon yang amat positif dari atlet, pelatih dan juga pengurus anggar di Jambi. Mereka mendapat kesempatan untuk dapat lebih kreatif mengolah bahan-bahan yang ada dan dapat digunakan dalam olahraga Anggar. 70\% responden yang meliputi atlet, pelatih dan pengurus Anggar di Universitas Jambi memberikan respon yang positif dan menyatakan kefektifan dari modifikasi senjata yang dibuat. Beberapa hal yang perlu ditingkatkan adalah kegunannya, dari yang tidak bisa digunakan untuk menusuk diharapkan kedepannya dapat dimodifikasi lagi serta dapat digunakan untuk menusuk.

Data dalam penelitian menggunakan konsep ADDIE, yaitu Analysis, Development, Design, Implementation, dan Evaluating. Berdasarkan dengan tahap Analisis, peneliti menelaah permasalahan yang timbul dalam kegiatan Anggar di FIK Universitas Jambi, salah satunya adalah belum kuatnya lengan yang dimiliki oleh atlet, sehingga belum kuat saat memegang senjata Anggar. Setelah hal tersebut diketahui, kemudian peneliti mulai mengembangkan cara-cara atau teknik dan taktik bagaimana meminimalisir kesalahan yang dimiliki oleh atlet, yaitu dengan memodifikasi senjata yang biasa mereka gunakan dalam berlatih dan bermain anggar.

Mendapatkan ide untuk membuat dan mekonsepkan senjata yang akan dimodifikasi, kemudian peneliti membuat design yang disesuaikan dengan atlet yang menjadi sasaran dan di sesuaikan pula dengan kebutuhan yang diinginkan. Dalam tahap implementasi, senjata yang telah dimodifikasi kemudian diuji cobakan kepada atlet pemula untuk dapat di review apakah dapat digunakan dengan baik sesuai dengan tujuan kegunaanya atau tidak. Tahap terakhir yaitu tahap evaluasi, peneliti mengevaluasi senjata yang telah dimodifikasi, meminta saran, kritik dan pendapat dari para atlet, setelah dirasa cukup dalam tahap evaluasi kemudian peneliti akan menggandakan senjata yang dimodifikasi tersebut untuk memenuhi kegunaan dan target yang ingin dicapai. 
Atri Widowati, Grafitte Decheline | Modifikasi Senjata Anggar Untuk Meningkatkan Kekuatan Otot Lengan Pada Atlet Anggar Pemula

\section{SIMPULAN}

Berdasarkan dengan berbagai pendapat dan jawaban dari atlet tentang efektivitas senjata anggar yang dimodifikasi, dapat disiimpulkan bahwa $70 \%$ senjata yang dimodifikasi memberikan efektivitas yang signnifikan terhadap latihan Anggar yang dilakukan oleh atlet pemula, sebelum mereka bisa menggunakan senjata anggar yang sebenarnya

\section{REFERENSI}

Cahyadi, R. A. H. (2019). Pengembangan Bahan Ajar Berbasis Addie Model. Halaqa: Islamic Education Journal, 3(1), 35. https://doi.org/10.21070/halaqa.v3i1.2124

Chan, F. (2012). Strength Training (Latihan Kekuatan). Cerdas Sifa.

Decheline, G., \& Rasyono. (2019). Pengaruh Variasi Latihan Serangan Terhadap Ketepatan Tusukan Atlet Anggar Provinsi Jambi. 8(2), 28-34.

Junaedi, D. (2016). Desain Pembelajran Model ADDIE. Jurnal Metode Pendidikan.

Keung, S. (2017). [EdTech] Web 2.0 and Animation Creation. https://medium.com/@sharonkhl/web-2-0-and-animation-creation-26ddaa252228

Kurniawan, F. (2010a). Analisis Secara Biomekanika Teknik Gerak Serang Dalam Anggar. Analisis Secara Biomekanika Teknik Gerak Serang Dalam Anggar.

Kurniawan, F. (2010b). Mengenal Cabang Olahraga Klasik, Anggar. Yogyakarta: FIK UNY.

Pertiwi, C. T. J. (2012). Profil Kondisi Fisik Atlet Anggar Di Kabupaten Purworejo Jawa Tengah Skripsi.

Sugiyono. (2014). Metode Penelitian Pendidikan pendekatan Kuantitatif, Kualitatif dan R\&D. In METODE PENELITIAN ILMIAH.

Metode Penelitian Kuantitatif, Kualitatif,dan R\&D, Alfabeta, cv. (2016).

Tegeh, I. M., \& Kirna, I. M. (2013). Pengembangan Bahan Ajar Metode Penelitian Pendidikan Dengan Addie Model. Jurnal Ika. 
PAJU Physical Activity Journal (PAJU) Vol. 2, No.1, 2020 Hal. 109-124

Widowati, A., \& Decheline, G. (2018). Latihan Shadow Fencing Anggar Untuk Atlet Anggar Provinsi Jambl. 2, 16-27.

wikipedia. (2020). Anggar. Wikipedia. https://id.wikipedia.org/wiki/Anggar 